\title{
Haloanaerobacter salinarius sp. nov., a novel halophilic fermentative bacterium that reduces glycine-betaine to trimethylamine with hydrogen or serine as electron donors; emendation of the genus Haloanaerobacter
}

\author{
Sophie Mouné, ${ }^{1}$ Nathalie Manac'h, ${ }^{3}$ Agnès Hirschler, ${ }^{2}$ Pierre Caumette, ${ }^{1} \dagger$ \\ John C. Willison ${ }^{3}$ and Robert Matheron ${ }^{2}$
}

Author for correspondence: Pierre Caumette. Tel: +33559923146 . Fax: + 33559808311 .
e-mail: pierre.caumette $@$ univ-pau.fr

1 Laboratoire d'Océanographie Biologique, Université Bordeaux 1, rue du Professeur Jolyet, F-33120 Arcachon, France

2 Laboratoire de Microbiologie, IMEP, Université Aix-Marseille III, F-13397 Marseille Cedex 20, France

3 Laboratoire de Biochimie et Biophysique des Systèmes Intégrés, DBMS/BBSI, CEA, 17 rue des Martyrs, F-38054 Grenoble Cedex 9, France

\begin{abstract}
A novel halophilic fermentative bacterium has been isolated from the black sediment below a gypsum crust and a microbial mat in hypersaline ponds of Mediterranean salterns. Morphologically, physiologically and genetically this organism belongs to the genus Haloanaerobacter. Haloanaerobacter strain SG $3903^{\top}$ ( $T$ = type strain) is composed of non-sporulating long flexible rods with peritrichous flagella, able to grow in the salinity range of $5-30 \% \mathrm{NaCl}$, with an optimum at $14-15 \%$. The strain grows by fermenting carbohydrates or by using the Stickland reaction with either serine or $\mathrm{H}_{2}$ as electron donors and glycine-betaine as acceptor, which is reduced to trimethylamine. The two species described so far in the genus Haloanaerobacter are not capable of Stickland reaction with glycine-betaine + serine; however, Haloanaerobacter chitinovorans can use glycine-betaine with $\mathrm{H}_{2}$ as electron donor. Strain SG $3903^{\top}$ thus represents the first described strain in the genus Haloanaerobacter capable of the Stickland reaction with two amino acids. Although strain SG $3903^{\top}$ showed $67 \%$ DNA-DNA relatedness to $H$. chitinovorans, it is physiologically sufficiently different from the two described species to be considered as a new species which has been named Haloanaerobacter salinarius sp. nov.
\end{abstract}

Keywords: marine salterns, halophilic fermentative bacteria, Haloanaerobacter, glycine-betaine, Stickland reaction

\section{INTRODUCTION}

The anoxic sediments of hypersaline environments are often characterized by a large number of halophilic anaerobic bacteria belonging to the domain Bacteria. Among them the most frequently isolated are fermentative bacteria (Rainey et al., 1995) and anoxygenic phototrophs (Ollivier et al., 1994; Imhoff \& Süling, 1996). Many types of halophilic bacteria have been isolated from the Dead Sea, inland salt lakes or

\footnotetext{
+Present address: Laboratoire d'Ecologie moléculaire-IBEAS, Université de Pau, Ave. de l'Université, F-64000 Pau, France.

The EMBL accession number for the $16 \mathrm{~S}$ rRNA sequence of SG $3903^{\top}$ is Y14212.
}

subterranean waters in oilfields (Oren, 1992; Ollivier et al., 1994; Rainey et al., 1995; Imhoff \& Sülling, 1996; Ravot et al., 1997). Some of them were isolated from thalassohaline environments such as solar salterns; they include phototrophic bacteria of the family Chromatiaceae (Caumette et al., 1988, 1991a, 1997), sulfate-reducing bacteria (Caumette et al., 1991b) and fermentative bacteria (Zhilina \& Zavarzin, 1990; Zhilina et al., 1991a, b, 1992; Liaw \& Mah, 1992; Simankova et al., 1993).

During ecological investigations in solar salterns of the French Mediterranean coast (Salin-de-Giraud, Camargue, Rhône Delta), we isolated several new species of phototrophs and sulfate reducers that developed at the sediment surface of certain hypersaline ponds characterized by gypsum deposits and 
salinities ranging from 15 to $30 \%$ (Caumette, 1993; Caumette et al., 1994). Recently a number of fermentative halophilic bacterial strains belonging to the order Haloanaerobiales were isolated from the black anoxic sediment of these ponds, where they co-exist with the sulfate reducers. So far, the order Haloanaerobiales contains 17 species, grouped into nine genera and two families, Haloanaerobiaceae and Halobacteroidaceae (Bhupathiraju et al., 1994; Cayol et al., 1995; Rainey et al., 1995; Tsai et al., 1995; Zhilina et al., 1996; Ravot et al., 1997). These species grow mainly by fermenting carbohydrates; one of them (Acetohalobium arabaticum) was found to be able to use amino acids such as glycine-betaine (Zhilina \& Zavarzin, 1990) which is a common compound in hypersaline environments and is used as compatible solute by a large variety of halophilic organisms and micro-organisms (Yancey et al., 1982; Galinski \& Trüper, 1994). Among our strains isolated from the Salin-de-Giraud salterns, several were able to use glycine-betaine as substrate; morphologically and physiologically, they were similar to Acetohalobium arabaticum. Others were found to be able to use glycine-betaine only in the presence of hydrogen or serine. One of these strains, strain SG $3903^{\mathrm{T}}$, was selected for further characterization. According to morphological, physiological and genetical studies, this strain was closely related to the species Haloanaerobacter chitinovorans, but sufficiently different to be proposed as a new species. This paper describes its characteristics in comparison with Haloanaerobacter chitinovorans, in particular its ability to carry out the Stickland reaction with glycine-betaine as electron acceptor and hydrogen or serine as electron donors. This strain SG $3903^{\mathrm{T}}$ is consequently proposed as a new species with the name Haloanaerobacter salinarius sp. nov.

\section{METHODS}

Sources of strains. Strain SG $3903^{\mathrm{r}}$ was isolated from the microbial mat at the sediment surface of hypersaline ponds where total salinity ranges from 13 to $20 \%$ depending of the seasons, in the saltern of Salin-de-Giraud (Camargue, France).

Haloanaerobacter lacunaris strain DSM $6640^{\mathrm{T}}$ and Haloanaerobacter chitinovorans OGC $229^{\mathrm{T}}$ (DSM 9569 $)$ were obtained from the DSM. Haloanaerobacter lacunaris (Zhilina et al., 1991b) originated from the silt of Lake Chokrak, Crimea (25\% total salinity) and Haloanaerobacter chitinovorans (Liaw \& Mah, 1992) was isolated from the sediment of salterns in Chula Vista, CA, USA (20-30\% total salinity).

Media, isolation and culture conditions. The basal synthetic medium used for the growth of strain SG $3903^{\mathrm{T}}$ contained, per litre of distilled water: $\mathrm{NaCl}, 150 \mathrm{~g} ; \mathrm{MgCl}_{2} .6 \mathrm{H}_{2} \mathrm{O}, 15 \mathrm{~g}$; $\mathrm{KCl}, 3 \mathrm{~g} ; \mathrm{NH}_{4} \mathrm{Cl}, 0.5 \mathrm{~g} ; \mathrm{KH}_{2} \mathrm{PO}_{4}, 0.35 \mathrm{~g} ; \mathrm{CaCl}_{2} .2 \mathrm{H}_{2} \mathrm{O}$, $0.05 \mathrm{~g}$; yeast extract, $0.1 \mathrm{~g} ; 0.1 \%$ resazurin solution, $1 \mathrm{ml}$; trace-element solution SL12 (Overmann et al., 1992), $1 \mathrm{ml}$; selenite-tungstate solution $\left(\mathrm{Na}_{2} \mathrm{SeO}_{3} .5 \mathrm{H}_{2} \mathrm{O}, 6 \mathrm{mg} \mathrm{l}^{-1}\right.$; $\left.\mathrm{Na}_{2} \mathrm{WO}_{4} .2 \mathrm{H}_{2} \mathrm{O}, 8 \mathrm{mg} \mathrm{l}^{-1} ; \mathrm{NaOH}, 0.4 \mathrm{~g} \mathrm{l}^{-1}\right), 1 \mathrm{ml} ; \mathrm{NaHCO}_{3}$, $2 \mathrm{~g} ; \mathrm{Na}_{2} \mathrm{~S} .9 \mathrm{H}_{2} \mathrm{O}, 0.5 \mathrm{~g}$; vitamin $\mathrm{V} 7$ solution (Pfennig et al., 1981), $1 \mathrm{ml} ; \mathrm{pH} 7 \cdot 2-7 \cdot 4$
The medium was prepared under a mixture of gas $\left(\mathrm{N}_{2} / \mathrm{CO}_{2}\right.$; $90: 10, \mathrm{v} / \mathrm{v}$ ) according to the method of Pfennig et al. (1981). Prior to utilization, the medium was supplemented with organic substrates as energy and carbon sources (see Table 1 for substrate utilization).

Pure cultures of strain SG $3903^{\mathrm{T}}$ were obtained from repeatedly prepared deep agar dilution series (Pfennig \& Trüper, 1981) in Hungate tubes with $\mathrm{H}_{2} / \mathrm{CO}_{2}(90: 10, \mathrm{v} / \mathrm{v})$ in the gas phase, and glycine-betaine as carbon source and electron acceptor. The tubes were incubated at $30^{\circ} \mathrm{C}$ in the dark.

Purity of the cultures was checked microscopically and by inoculation into different media specific for aerobic bacteria and sulfate reducing bacteria.

Pure strains were grown in liquid cultures under a gas phase $\left(\mathrm{H}_{2} / \mathrm{CO}_{2} ; 90: 10, \mathrm{v} / \mathrm{v}\right)$ in $60 \mathrm{ml}$ serum bottles stoppered with butyl rubber stoppers, using the Hungate anaerobic technique. The basal medium was supplemented with glycinebetaine $+\mathrm{H}_{2}$ or with glycine-betaine + serine. After growth at $30^{\circ} \mathrm{C}$, the strains were then stored at $4{ }^{\circ} \mathrm{C}$ in the dark, for periods of 2-4 months.

Microscopy. Microscopic observations and photomicrographs were made with an Olympus photomicroscope (OM2) according to the method of Pfennig \& Wagener (1986). Flagella were observed by transmission electron microscopy with a JEOL 1200 ES electron microscope after negative staining with $1 \%(\mathrm{w} / \mathrm{v})$ tungstic acid neutralized to $\mathrm{pH} 7 \cdot 2$. The fine structure of the cells was studied by transmission electron microscopy after fixation of a cell pellet with osmic acid and ultrathin sectioning of the cells according to Glazer et al. (1971).

Physiological tests. Utilization of carbon sources and electron donors was tested in triplicate in basal liquid medium with substrate concentrations as given in Table 1. Growth tests for utilizable substrates, the utilization of optimum concentrations of $\mathrm{NaCl}$ and $\mathrm{MgCl}_{2} \cdot 6 \mathrm{H}_{2} \mathrm{O}$, optimum $\mathrm{pH}$, optimum temperature and sulfide tolerance were performed in completely filled $25 \mathrm{ml}$ screw-cap tubes as described by Caumette et al. (1988).

For aerobic growth tests, the basal medium without hydrogen carbonate and sulfide was buffered with $0.4 \mathrm{M}$ Tris $/ \mathrm{HCl}$ and supplemented with glucose as substrate. The growth was checked in test tubes open to air through a cotton stopper. Antibiotic and antibacterial susceptibility was tested in completely filled screw-cap tubes with the growth medium for maintenance of strains supplemented with the following substances: anisomycin $\left(40 \mu \mathrm{g} \mathrm{ml}^{-1}\right)$, chloramphenicol $\left(20 \mu \mathrm{g} \mathrm{ml}^{-1}\right)$, tetracycline $\left(40 \mu \mathrm{g} \mathrm{ml}^{-1}\right)$, erythromycin $\left(40 \mu \mathrm{g} \mathrm{ml}^{-1}\right)$ kanamycin $\left(40 \mu \mathrm{g} \mathrm{ml}^{-1}\right)$ and sodium taurocholate $\left(50 \mu \mathrm{g} \mathrm{ml}^{-1}\right)$ according to the method described by Oren (1990).

Growth was measured by following the optical density of cultures at $450 \mathrm{~nm}$ (Bausch \& Lomb; Spectronic 20) over a period of $10 \mathrm{~d}$.

Vitamin requirement was tested in $60 \mathrm{ml}$ serum bottles by growth tests through five consecutive transfers in synthetic medium free of vitamins and yeast extract. Catalase was tested by adding a few drops of $3 \%(\mathrm{v} / \mathrm{v}) \mathrm{H}_{2} \mathrm{O}_{2}$ to a cell pellet on a microscope slide. Utilization of sulfate, sulfite, thiosulfate or nitrate was tested in Postgate medium B (Postgate, 1984), previously made free of sulfate, in $60 \mathrm{ml}$ serum bottles, with glucose as electron donor. After growth, sulfur 
compound utilization was determined by sulfide production, as revealed by the formation of a black precipitate of $\mathrm{FeS}$ in the liquid culture; nitrate reduction was determined by nitrite production revealed by the formation of a red colour upon addition of Griess reagent.

Analytical procedures. The presence of $\mathrm{H}_{2}$ and $\mathrm{CO}_{2}$ among fermentation products was detected with a Chrompack $\mathrm{CP}$ 9001 gas chromatograph equipped with a thermal conductivity detector $\left(135^{\circ} \mathrm{C}\right)$ and a semi-capillary column Poraplot Q $\left(25 \mathrm{~m}\right.$ long, $0.53 \mathrm{~mm}$ i.d.) operated at $35^{\circ} \mathrm{C}$ with $\mathrm{N}_{2}\left(12 \mathrm{ml} \mathrm{min}^{-1}\right)$ or helium $\left(12 \mathrm{ml} \mathrm{min}^{-1}\right)$ as the carrier gases for $\mathrm{H}_{2}$ or $\mathrm{CO}_{2}$ detections, respectively.

A flame-ionization detector $\left(220^{\circ} \mathrm{C}\right)$ was used for alcohol determination with the same column operated at $150^{\circ} \mathrm{C}$ with helium $\left(12 \mathrm{ml} \mathrm{min}^{-1}\right)$ as the carrier gas.

Methylamines were determined by gas chromatography using the same gas chromatograph equipped with a $3 \mathrm{~m} \times 3.1 \mathrm{~mm}$ column (Chromosorb 103, 80/100 mesh) and with a flame-ionization detector $\left(200^{\circ} \mathrm{C}\right)$. The column was operated at $110^{\circ} \mathrm{C}$ with helium $\left(25 \mathrm{ml} \mathrm{min}{ }^{-1}\right)$ as the carrier gas. Before injection, samples of cell-free culture medium were prepared according to the method of Hippe et al. (1979).

Organic acids were determined with a HPLC apparatus, equipped with a Shimadzu LC 6A pump, a PYE Unicam UV detector (at $210 \mathrm{~nm}$ ) and a Rezex-type organic acid (Phenomenex) column $(300 \times 7.8 \mathrm{~mm}) ; 0.005 \mathrm{M} \mathrm{H}_{2} \mathrm{SO}_{4}$ was used as the solvent at a flow rate of $0.5 \mathrm{ml} \mathrm{min}{ }^{-1}$. The volume of the injection loop was $20 \mu$ l.

Glycine-betaine and serine were analysed with the same HPLC fitted with a Hypersil- $\mathrm{NH}_{2}$ column (Touzart and Matignon); acetonitrile/10 mM phosphate buffer $\mathrm{pH} 7$ $(75 / 25)$ solution was used as the solvent at a flow rate of

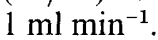

\section{DNA base composition, sequence of the 165 rDNA gene and DNA-DNA hybridization}

Isolation of genomic DNA. Strain SG $3903^{\mathrm{T}}$ was grown on $\mathrm{H}_{2}+$ glycine-betaine, lyophilized, and stored under 2-propanol. Before use, the cells were centrifuged to remove 2-propanol, and resuspended and washed in $0.1 \% \mathrm{SDS} / 10 \mathrm{mM}$ Tris/ $\mathrm{HCl} / 1 \mathrm{mM}$ EDTA, pH 8.0 (Vargas et al., 1995). Genomic DNA was then prepared as described by Ausubel et al. (1989).

Determination of $\mathrm{G}+\mathrm{C}$ content. The $\mathrm{G}+\mathrm{C}$ content of genomic DNA from SG $3903^{\mathrm{T}}$ was determined by high-performance liquid chromatography as decribed by Mesbah et al. (1989), using bacteriophage lambda DNA as standard.

Amplification of $16 \mathrm{~S}$ rDNA by PCR. A $1.4 \mathrm{~kb}$ fragment of the gene encoding 16S rRNA was amplified by PCR using the following primers specified by Amann et al. (1995): sense primer, 5'AGAGTTTGATCCTGGCTCA3'. Bacteria, positions 8-26 (Escherichia coli numbering); antisense primer, 5'ACGGGCGGTGTGTA(G)C3', Universal, positions 1406-1392 (E. coli numbering). The PCR reaction mixture contained (in $100 \mu \mathrm{l}): 0 \cdot 5 \mu \mathrm{g}$ genomic DNA; $200 \mathrm{pmol}$ each primer; $50 \mathrm{mM} \mathrm{KCl} ; 10 \mathrm{mM}$ Tris $/ \mathrm{HCl}$, pH $9.0 ; 0.1 \%$ Triton X-100;1.25 mM MgCl${ }_{2} ; 0.2 \mathrm{mM}$ each dNTP; $5 \%(\mathrm{v} / \mathrm{v})$ DMSO; $2.5 \mathrm{U}$ Taq DNA polymerase (Promega). An initial cycle composed of 3 min denaturation at $94^{\circ} \mathrm{C}, 2 \mathrm{~min}$ annealing at $50^{\circ} \mathrm{C}$, and $3 \mathrm{~min}$ extension at
$72{ }^{\circ} \mathrm{C}$ was followed by 34 cycles of $1 \mathrm{~min}$ at $94{ }^{\circ} \mathrm{C}, 2 \mathrm{~min}$ at $50^{\circ} \mathrm{C}$ and $3 \mathrm{~min}$ at $72{ }^{\circ} \mathrm{C}$.

Cloning and sequencing of the PCR product. The PCR reaction mixture was extracted with $100 \mu \mathrm{l}$ chloroform/isoamyl alcohol $(24: 1)$ and purified by centrifugation through a MicroSpin S-400 HR column (Pharmacia Biotech). After treatment with T4 DNA polymerase to remove protruding $\mathrm{dA}$ residues (Sambrook et al., 1989), the $1.4 \mathrm{~kb}$ PCR product was cloned into the SmaI site of pUC19. The cloned insert was then sequenced entirely on both strands, using Sequenase enzyme (USB Biochemicals). The resulting sequence (1383 nucleotides) is EMBL accession number Y14212.

Genetic analysis. The $16 \mathrm{~S}$ rRNA/rDNA sequences of 14 species of fermentative halophilic anaerobic bacteria were obtained from the EMBL Database, using the accession numbers quoted by Rainey et al. (1995). The following strains were used (sequence accession numbers in parentheses): Haloanaerobium praevalens DSM 2228 ${ }^{\mathrm{T}}$ (M59123), Haloanaerobium alcaliphilum DSM 8275 $\quad$ (X81850), Haloanaerobium saccharolyticum subsp. saccharolyticum DSM 6643 ${ }^{\mathrm{T}}$ (X89069), Haloanaerobium saccharolyticum subsp. senegalense DSM $7379^{\mathrm{T}}$ (X89070), Haloanaerobium acetoethylicum DSM 3532 ${ }^{\mathrm{T}}$ (X89071), Haloanaerobium

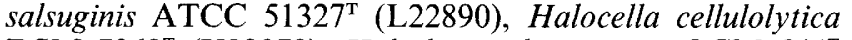
DSM $7362^{\mathrm{T}}$ (X89072), Halothermothrix orenii OCM $544^{\mathrm{T}}$ (L22016), Haloanaerobacter chitinovorans OGC $229^{\mathrm{T}}$ (X89076), Haloanaerobacter lacunaris DSM 6640 ${ }^{\mathrm{T}}$ (X89075), Halobacteroides halobius DSM 5150 ${ }^{\mathrm{T}}$ (X89074), Orenia marismortui DSM 5156 ${ }^{\mathrm{T}}$ (X89073), Sporohalobacter lortetii DSM $3070^{\mathbf{T}}$ (M59122), Acetohalobium arabaticum DSM $5501^{\mathrm{T}}$ (X89077) and Megasphaera elsdenii (M26493). The database entry for Haloanaerobium acetoethylicum (X89071) was found to be identical to that for Haloanaerobium saccharolyticum subsp. senegalense (X89070), but this has since been corrected ( $\mathrm{F}$. Rainey, personal communication). These sequences were aligned with the strain SG $3903^{\mathrm{T}}$ sequence by the CLUSTAL $w$ method, using the MEGALIGN program of the DNAstar software package. The alignment was then modified to remove regions containing unidentified bases or gaps of more than three nucleotides. The subsequent analysis was based on a comparison of approximately 1240 nucleotides.

DNA-DNA hybridization. The DNA-DNA hybridization was performed between strain SG $3903^{\mathrm{T}}$ and Haloanaerobacter chitinovorans OGC $229^{\mathrm{T}}$. The test was carried out at the Identification Service of DSMZ (Braunschweig, Germany). DNA was isolated by chromatography on hydroxyapatite by the procedure of Cashion et al. (1977). DNA-DNA hybridization was carried out as described by De Ley et al. (1970), with the modification described by Huss et al. (1983) and Escara \& Hutton (1980) using a Gilford System model 2600 spectrometer equipped with a Gilford model 2527-R thermoprogrammer and plotter. Renaturation rates were computed with the TRANSFER . BAS program by Jahnke (1992).

\section{RESULTS}

\section{Enrichment and isolation}

Different kinds of fermentative bacteria were enriched from black anoxic sediment below a thin laminated photosynthetic microbial mat and a gypsum crust in hypersaline ponds of Salin-de-Giraud (Camargue, 


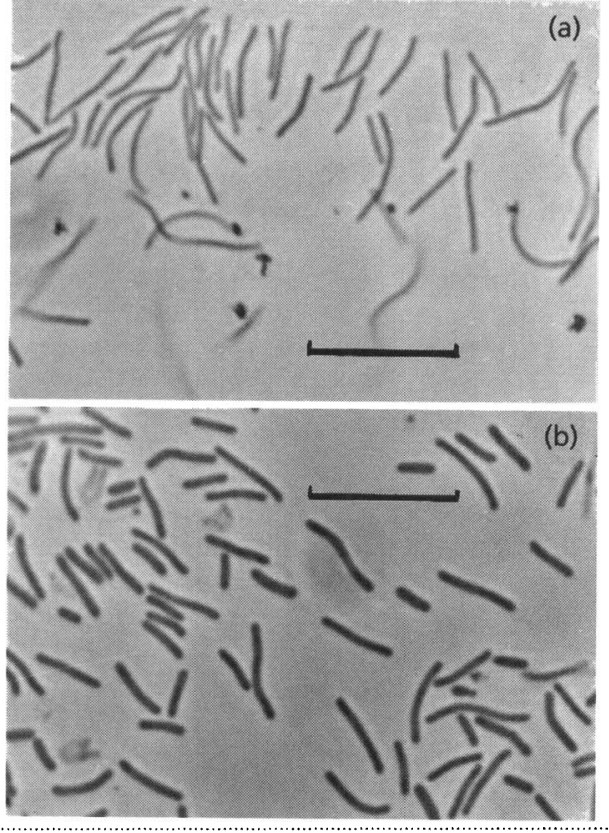

Fig. 1. Phase-contrast photomicrograph of Haloanaerobacter salinarius strain SG $3903^{\top}$ in liquid culture with (a) glycinebetaine $+\mathrm{H}_{2}$ or (b) glucose as substrates. Bar, $10 \mu \mathrm{m}$.

France) where the salinity ranged between 13 and $20 \%$. The laminated microbial mat was composed of halophilic phototrophic purple bacteria, as described previously (Caumette et al., 1988, 1991a). From the anoxic sediment, rich in acid-volatile sulfide due to a high sulfate reduction activity (Caumette et al., 1994), the enrichment culture of fermentative bacteria showed a large variety of cell types.

Several strains were purified and isolated by using different fermentable substrates such as glucose, glycine-betaine or glycine-betaine + hydrogen. Among the pure strains obtained, some were facultative anaerobes resembling vibrios, others were strict anaerobes able to ferment mainly glucose or, in a few cases, glycine-betaine. Some strains needed $\mathrm{H}_{2}$ to degrade glycine-betaine to trimethylamine; one of these, strain SG $3903^{\mathrm{T}}$, was selected for further characterization.

\section{Morphology and fine structure}

The individual cells of strain SG $3903^{\mathrm{T}}$ were long, thin, flexible rods, $0.3-0.4 \mu \mathrm{m}$ in width and 5-8 $\mu \mathrm{m}$ in length, in young cultures grown with glycine-betaine $+\mathrm{H}_{2}$ (Fig. 1a). When cultured with glucose as substrate, single cells were larger and less flexible (Fig. 1b). After the end of exponential growth, they rapidly formed sphaeroplasts.

The cells were motile. Negatively stained cells showed peritrichous flagella (data not shown). Electron microscopic examination of thin sections of strain SG $3903^{\mathrm{T}}$ revealed a typical Gram-negative layered cell envelope
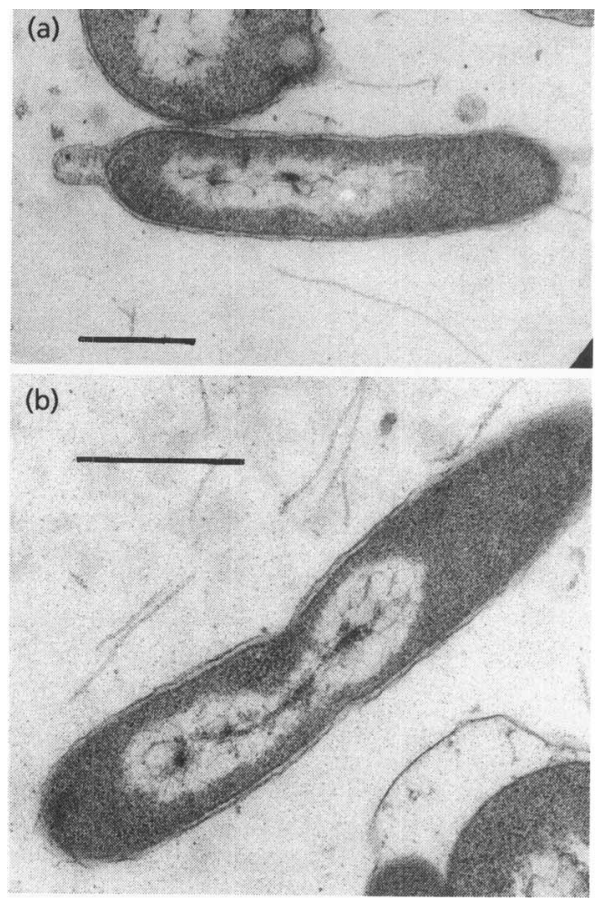

Fig. 2. Electron micrographs of Haloanaerobacter salinarius strain SG $3903^{\top}$. Ultrathin sections showing (a) the Gramnegative structure and the formation of sphaeroplasts and (b) cell division. Bars, $1 \mu \mathrm{m}$.

(Fig. 2a, b). In aged cultures, distortion of the envelope and formation of degenerate cells and sphaeroplasts were detected (Fig. 2a). Endospores were not detected by either phase-contrast microscopy or electron microscopy, not even after pasteurization $\left(80^{\circ} \mathrm{C}, 20 \mathrm{~min}\right)$ of the samples. Colonies were translucent and glossy in surface agar and opaque in deep agar. They were white to slightly yellow with entire edges; their diameter ranged from 1 to $2 \mathrm{~mm}$.

\section{Growth and physiology}

Strain SG $3903^{\mathrm{T}}$ grew over a large range of salinity (Fig. 3a). Growth was observed at $\mathrm{NaCl}$ concentrations between 5 and $30 \%(\mathrm{w} / \mathrm{v})$, with optimal growth at $14-15 \%$. At the optimal $\mathrm{NaCl}$ concentration, the optimal temperature for growth of strain SG $3903^{\mathrm{T}}$ was $45^{\circ} \mathrm{C}$ (Fig. 3b) and growth occurred at temperatures between 10 and $50^{\circ} \mathrm{C}$. The optimum $\mathrm{pH}$ was 7.4-7.8 and growth was possible between $\mathrm{pH} 5.5$ and $\mathrm{pH} 8.5$. For optimal growth, strain $\mathrm{SG} 3903^{\mathrm{T}}$ required a minimum of $1 \mathrm{mM} \mathrm{Mg}{ }^{2+}$. No growth was obtained in the presence of oxygen.

The strain showed a high sulfide tolerance, up to $14 \mathrm{mM}$. Neither growth factors nor vitamins were required.

Strain SG $3903^{\mathrm{T}}$ was not capable of dissimilatory reduction of inorganic nitrogen $\left(\mathrm{NO}_{3}^{-}\right)$or sulfur compounds $\left(\mathrm{SO}_{4}^{2-}, \mathrm{SO}_{3}^{2-}, \mathrm{S}_{2} \mathrm{O}_{3}^{2-}\right)$ thus showing a strict 


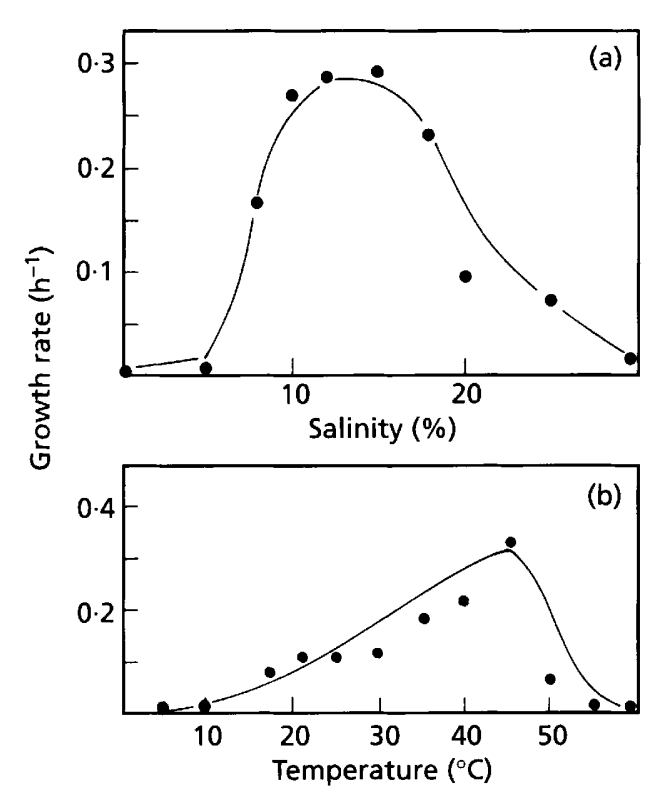

Fig. 3. Growth of Haloanaerobacter salinarius strain SG $3903^{\top}$ in liquid culture as a function of (a) salinity and (b) temperature. The growth rate has been calculated from exponential growth measured by $\mathrm{OD}_{450}$.

fermentative metabolism. Catalase test was negative. The strain did not use sulfate or nitrate as sulfur or nitrogen sources but it could use cysteine as both nitrogen and sulfur source. Strain SG $3903^{\mathrm{T}}$ was sensitive to chloramphenicol and erythromycin. Anisomycin, kanamycin, tetracycline, or $\mathrm{Na}$ taurocholate did not inhibit growth. Strain SG $3903^{\mathrm{T}}$ used the following fermentable substrates: glucose, fructose, galactose, mannose, trehalose, sucrose, maltose, raffinose, cellobiose, glucosamine, $\mathrm{N}$-acetylglucosamine and mannitol (Table 1).

The strain was also able to use glycine-betaine in the presence of an electron donor (hydrogen or serine) via a Stickland reaction (Fig. 4). Other amino acids were tested but were not able to act as electron donors for the reduction of glycine-betaine. With other amino acid pairs, the Stickland reaction was not observed in the strain SG $3903^{\mathrm{T}}$. Neither glycine-betaine nor serine alone were used as fermentable substrates (Fig. 4).

Fermentation products are listed in Table 2. From glucose as substrate, the major products obtained were ethanol, acetate, formate, propionate, $\mathrm{CO}_{2}$ and $\mathrm{H}_{2}$. Lactate was detected in very low concentrations. When glycine-betaine $+\mathrm{H}_{2}$ were used as substrates, strain $\mathrm{SG}$ $3903^{\mathrm{T}}$ excreted acetate, 2-propanol, trimethylamine and $\mathrm{CO}_{2}$. In the Stickland reaction with glycine-betaine and serine the strain produced acetate, trimethylamine, $\mathrm{CO}_{2}$ and $\mathrm{NH}_{3}$. Formate and acetate were also detected in very low concentrations. Monomethylamine, dimethylamine, dimethylglycine and sarcosine were never detected as fermentation products of glycinebetaine with either $\mathrm{H}_{2}$ or serine as electron donors.

As strain SG $3903^{\mathrm{T}}$ proved to be genetically closely related to Haloanaerobacter (see below), Haloanaerobacter chitinovorans OGC $229^{\mathrm{T}}$ and Haloanaerobacter lacunaris DSM $6640^{\mathrm{T}}$ were tested for possible Stickland reactions. Haloanaerobacter lacunaris was not able to use glycine-betaine with either serine or hydrogen, whereas Haloanaerobacter chitinovorans used only glycine-betaine + hydrogen for growth.

\section{Genomic characteristics and genetic relationships}

The DNA base composition of strain SG $3903^{\mathrm{T}}$ was $31.6 \mathrm{~mol} \% \mathrm{G}+\mathrm{C}$. A near complete sequence $(1383$ nucleotides) of the $16 \mathrm{~S}$ rRNA gene of strain SG $3903^{\mathrm{T}}$ was determined. The sequence (positions 8-1406, E. coli numbering according to Winker \& Woese, 1991) was aligned and a genetic analysis was performed with 16S rRNA gene sequences of 14 representatives of the closest phyla in the domain Bacteria. A distance matrix based on the Jukes \& Cantor (1969) method showing the percentage similarities and divergences between the different sequences has been constructed. The sequence from Megasphaera elsdenii was included as the outgroup for rooting the dendrogram. The dendrogram derived from the distance matrix is shown in Fig. 5. The tree clearly shows the branching of the fermentative halophilic anaerobic bacteria into two clusters (Patel et al., 1995) or families (Rainey et al., 1995). Strain SG $3903^{\text {T }}$ was most closely related to Haloanaerobacter chitinovorans $(98.9 \%$ similarity) and Haloanaerobacter lacunaris $(97.5 \%$ similarity). These last two species showed a similarity of $98.1 \%$ to each other. The closest species in the neighbouring genus was Halobacteroides halobius, which showed a similarity with strain SG $3903^{\mathrm{T}}$, Haloanaerobacter chitinovorans and Haloanaerobacter lacunaris of $85 \cdot 6,86 \cdot 2$ and $86.6 \%$, respectively.

As strain SG $3903^{\mathrm{T}}$ and Haloanaerobacter chitinovorans were very closely related ( $98.9 \%$ similarity), a DNA-DNA hybridization was performed between strain SG $3903^{\mathrm{T}}$ and Haloanaerobacter chitinovorans OGC $229^{\mathrm{T}}$. The DNA-DNA pairing value obtained was $67 \%$.

\section{DISCUSSION}

Strain SG $3903^{\mathrm{T}}$ is a Gram-negative, flexible, long, rod-shaped, carbohydrate fermenting, non-sporeforming, halophilic anaerobe which grows in the presence of $50-300 \mathrm{~g} \mathrm{NaCl}^{-1}$. These characteristics and its $\mathrm{G}+\mathrm{C}$ content $(31.6 \mathrm{~mol} \%)$ are consistent with assignment of strain SG $3903^{\mathrm{T}}$ to the family Halobacteroidaceae (Rainey et al., 1995). The genetic relatedness study based on comparison of $16 \mathrm{~S}$ rDNA sequences showed that strain $\mathrm{SG} 3903^{\mathrm{T}}$ is clearly a member of this family (Fig. 5). In the cluster of Halobacteroidaceae, strain SG $3903^{\mathrm{T}}$ is included with the group forming the genus Haloanaerobacter which is, so far, composed of two species: Haloanaerobacter chitinovorans and Haloanaerobacter lacunaris (Liaw \& 
Table 1. Substrate fermentation by Haloanaerobacter strain SG $3903^{\top}$ grown with $15 \% \mathrm{NaCl}$ under optimal conditions

+ , Substrate utilized; - , substrate not utilized. The following substrates were not used by strain SG $3903^{\mathrm{T}}$ (mM except where stated): arabinose (6); inulin (6); dextran (6); xylan (6); salicin (6); gluconate (6); dextrin (6); lactose (6); melizitose (6); rhamnose (6); sorbose (6); xylose (6); glycogen (6); ascorbate (6); inositol (6); sorbitol (6); ethanol (6); methanol (6); dulcitol (6); adonitol (6); valine (6); sarcosin (10); threonine (6); ornithine (6); glycine (6); proline (6); leucine (6); isoleucine (6); tryptophan (6); phenylalanine (6); alanine (6); histidine (6); urea (6); gelatin $(0.1 \%)$; pectin $(0.1 \%)$; yeast extract $(0.1 \%)$; crotonate (6). The following amino acid pairs were tested but were not utilized: glycinebetaine + glycine ; glycine-betaine + alanine; glycinebetaine + leucine; glycine-betaine + isoleucine; glycinebetaine + valine; glycine-betaine + phenylalanine; glycinebetaine + histidine; glycine-betaine + threonine; glycinebetaine + proline; glycine-betaine + ornithine; glycinebetaine + tryptophane; alanine + glycine; leucine + proline; isoleucine + proline; valine + ornithine;

phenylalanine + leucine; histidine + sarcosin.

\begin{tabular}{|lc|}
\hline Substrate & Utilization \\
\hline Glucose $(6 \mathrm{mM})$ & + \\
Fructose $(6 \mathrm{mM})$ & + \\
Galactose $(6 \mathrm{mM})$ & + \\
Mannose $(6 \mathrm{mM})$ & + \\
Trehalose $(6 \mathrm{mM})$ & + \\
Sucrose $(6 \mathrm{mM})$ & + \\
Maltose $(6 \mathrm{mM})$ & + \\
Raffinose $(6 \mathrm{mM})$ & + \\
Cellobiose $(6 \mathrm{mM})$ & + \\
Starch $(0 \cdot 1 \%)$ & - \\
Glucosamine $(6 \mathrm{mM})$ & + \\
$N$-Acetylglucosamine $(6 \mathrm{mM})$ & + \\
Chitin $(0 \cdot 1 \%)$ & - \\
Mannitol $(6 \mathrm{mM})$ & + \\
Pyruvate $(6 \mathrm{mM})$ & - \\
Malate $(6 \mathrm{mM})$ & - \\
Lactate $(6 \mathrm{mM})$ & - \\
Glutamate $(6 \mathrm{mM})$ & - \\
Glycine-betaine $(6 \mathrm{mM})$ & - \\
Glycine-betaine $(6 \mathrm{mM})+\mathrm{H}_{2}\left(10^{5} \mathrm{~Pa}\right)$ & + \\
Serine $(6 \mathrm{mM})$ & - \\
Glycine-betaine $(6 \mathrm{mM})+$ serine $(6 \mathrm{mM})$ & - \\
Trimethylamine $(6 \mathrm{mM})$ & - \\
\hline
\end{tabular}

Mah, 1992; Zhilina et al., 1991b). Strain SG 3903, which may be considered as a new representative of the genus Haloanaerobacter, is most closely related to the species Haloanaerobacter chitinovorans. However, on the basis of its $\mathrm{G}+\mathrm{C}$ content, Haloanaerobacter strain SG $3903^{\mathrm{T}}(31.6 \mathrm{~mol} \%)$ is closer to Haloanaerobacter lacunaris $(32.4 \mathrm{~mol} \%)$ than to Haloanaerobacter chitinovorans $(34.8 \mathrm{~mol} \%)$. In addition, the percentage of the DNA-DNA hybridization between Haloanaerobacter chitinovorans and our strain is $67 \%$,

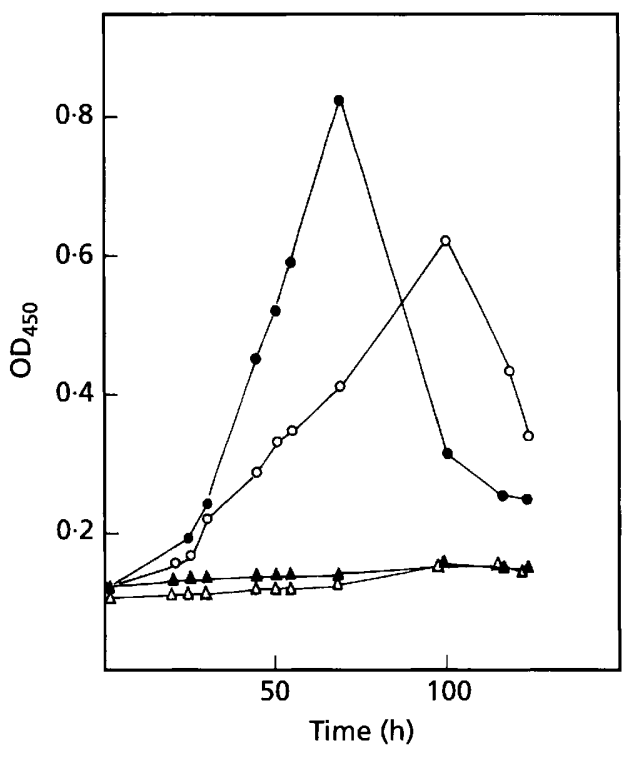

Fig. 4. Growth of Haloanaerobacter salinarius strain SG $3903^{\top}$ in liquid cultures with different substrates (A) with glycinebetaine alone; $(\triangle)$ with serine alone; $(\Theta)$ with glycinebetaine + serine (Stickland reaction); $(O)$ with glycine-betaine + hydrogen.

indicating that strain $\mathrm{SG} 3903^{\mathrm{T}}$ is close to the species Haloanaerobacter chitinovorans.

Like Haloanaerobacter chitinovorans and Haloanaerobacter lacunaris, Haloanaerobacter strain SG $3903^{\mathrm{T}}$ was isolated from a thalassohaline environment (hypersaline lagoon or saltern). These bacteria, with salinity optima between 12 and $18 \%$, are well adapted to the salinity of their environments (Table 3 ). They grow by fermenting mainly carbohydrates. They are not able to use amino acids as sole substrates (Liaw \& Mah, 1992). However, the data demonstrated that our strain Haloanaerobacter SG $3903^{\mathrm{T}}$ was able to reduce glycine-betaine to trimethylamine with hydrogen or serine as electron donors (Fig. 4). In contrast, Haloanaerobacter lacunaris was not capable of glycinebetaine reduction whereas Haloanaerobacter chitinovorans could use glycine-betaine only with hydrogen. Thus, bacteria belonging to the genus Haloanaerobacter do not use exclusively carbohydrates as stated by Liaw \& Mah (1992), but some strains or species can also use certain amino acids mainly glycinebetaine via a Stickland reaction with serine or $\mathbf{H}_{2}$ as electron donors.

In our strain, Haloanaerobacter SG $3903^{\mathrm{T}}$, glucose and glycine-betaine were fermented according to the following equations (Table 2 ):

$4 \cdot 17$ glucose $\rightarrow 3$ ethanol +3 propionate +2

acetate + formate $+5 \mathrm{CO}_{2}+\mathrm{H}_{2}$

2.5 glycine-betaine $+4.05 \mathrm{H}_{2} \rightarrow 2$-propanol +2.5

trimethylamine +0.95 acetate $+0 \cdot 1 \mathrm{CO}_{2}+1.9 \mathrm{H}_{2} \mathrm{O}$

glycine-betaine $+1 \cdot 32$ serine $+\mathrm{H}_{2} \mathrm{O} \rightarrow$

trimethylamine +2 acetate $+1 \cdot 32 \mathrm{CO}_{2}+1 \cdot 32 \mathrm{NH}_{3}$ 
Table 2. Fermentation products and fermentation balance obtained after growth of Haloanaerobacter strain SG $3903^{\top}$ with different substrates under optimal conditions

\begin{tabular}{|c|c|c|c|c|}
\hline Substrates and products & $\begin{array}{l}\text { Concn } \\
(\mathrm{mM})\end{array}$ & $\begin{array}{c}\text { Oxidation } \\
\text { degree }\end{array}$ & $\begin{array}{c}\text { Oxidation degree } \\
\text { per equation }\end{array}$ & Sum \\
\hline \multicolumn{5}{|l|}{ Substrate: } \\
\hline Glucose & $4 \cdot 17$ & 0 & 0 & 0 \\
\hline \multicolumn{5}{|l|}{ Products: } \\
\hline Ethanol & 3 & -2 & -6 & \\
\hline Acetate & 2 & 0 & 0 & \\
\hline Formate & 1 & +1 & +1 & \\
\hline Propionate & 3 & -1 & -3 & \\
\hline Carbon dioxide & 5 & +2 & +10 & \\
\hline Hydrogen & 2 & -1 & -2 & 0 \\
\hline \multicolumn{5}{|l|}{ Substrates: } \\
\hline Hydrogen & 4.05 & -1 & -4.05 & \\
\hline Glycine-betaine & $2 \cdot 5$ & -4 & -10 & -14.05 \\
\hline \multicolumn{5}{|l|}{ Products: } \\
\hline Acetate & 0.95 & 0 & 0 & \\
\hline 2-Propanol & 1 & -3 & -3 & \\
\hline Trimethylamine & $2 \cdot 5$ & $-4 \cdot 5$ & $-11 \cdot 25$ & \\
\hline Carbon dioxide & $0 \cdot 1$ & +2 & $+0 \cdot 2$ & -14.05 \\
\hline \multicolumn{5}{|l|}{ Substrates: } \\
\hline Serine & $1 \cdot 32$ & -0.5 & $-0 \cdot 66$ & \\
\hline Glycine-betaine & 1 & -4 & -4 & $-4 \cdot 66$ \\
\hline \multicolumn{5}{|l|}{ Products: } \\
\hline Acetate & $2 \cdot 32$ & 0 & 0 & \\
\hline Trimethylamine & 1 & $-4 \cdot 5$ & $-4 \cdot 5$ & \\
\hline Carbon dioxide & $1 \cdot 32$ & +2 & $+2 \cdot 64$ & \\
\hline $\mathrm{NH}_{3}$ & $1 \cdot 32$ & -1.5 & -1.98 & $-3 \cdot 84$ \\
\hline
\end{tabular}

During the reduction of glycine-betaine with serine as electron donor, an additional product should be formed for a stoichiometric equilibrium in equation 3 . This product was not detected during analysis.

The use of glycine-betaine is of ecological importance in hypersaline environments. Glycine-betaine is a compatible solute synthesized and stored in a large variety of organisms (Yancey et al., 1982) and bacteria (Galinski \& Trüper, 1994); it is one of the major osmolytes in halophilic bacteria and thus widely distributed in hypersaline ecosystems with microbial mats. It is thus not surprising to find bacteria able to use this compound as substrate in such environments.

So far, only one species of halophilic fermentative bacteria Acetohalobium arabaticum (Zhilina \& Zavarzin, 1990) has been described as able to use glycine-betaine as sole substrate for growth.

However, two marine fermentative bacteria (Clostridium halophilum and Clostridium litorale) are able to use glycine-betaine via a Stickland reaction (Fendrich et al., 1990), and many other non halophilic bacteria have been described as able to reductively cleave glycine-betaine into acetate and trimethylamine (Naumann et al., 1983; Möller et al., 1984, 1986; Heijthuijsen \& Hansen, 1989).
In hypersaline environments, two genera are thus currently considered to be able to degrade glycinebetaine: the genus Acetohalobium and the genus Haloanaerobacter. In the genus Haloanaerobacter, strain SG $3903^{\mathrm{T}}$ is close to the species Haloanaerobacter chitinovorans but is sufficiently separated to be considered as a new species. Particularly, Haloanaerobacter strain SG $3903^{\mathrm{T}}$ is able to use glycine-betaine via a real Stickland reaction with two amino acids (glycine-betaine and serine) whereas Haloanaerobacter chitinovorans strain OGC $229^{\mathrm{T}}$ cannot; it can reduce glycine-betaine only with hydrogen. These unusual physiological traits are sufficient to consider strain $\mathrm{SG} 3903^{\mathrm{T}}$ as a new representative of the genus Haloanaerobacter although the DNA-DNA homology between our strain and its closest relative in the genus (Haloanaerobacter chitinovorans) was only $67 \%$.

According to these unusual physiological features, we propose Haloanaerobacter strain SG $3903^{\mathrm{T}}$ as the type strain of a new species with the name Haloanaerobacter salinarius $\mathrm{sp}$. nov.

\section{Emended description of the genus Haloanaerobacter}

Haloanaerobacter gen. emend.: full description is by Liaw \& Mah (1992), with additional features: some 


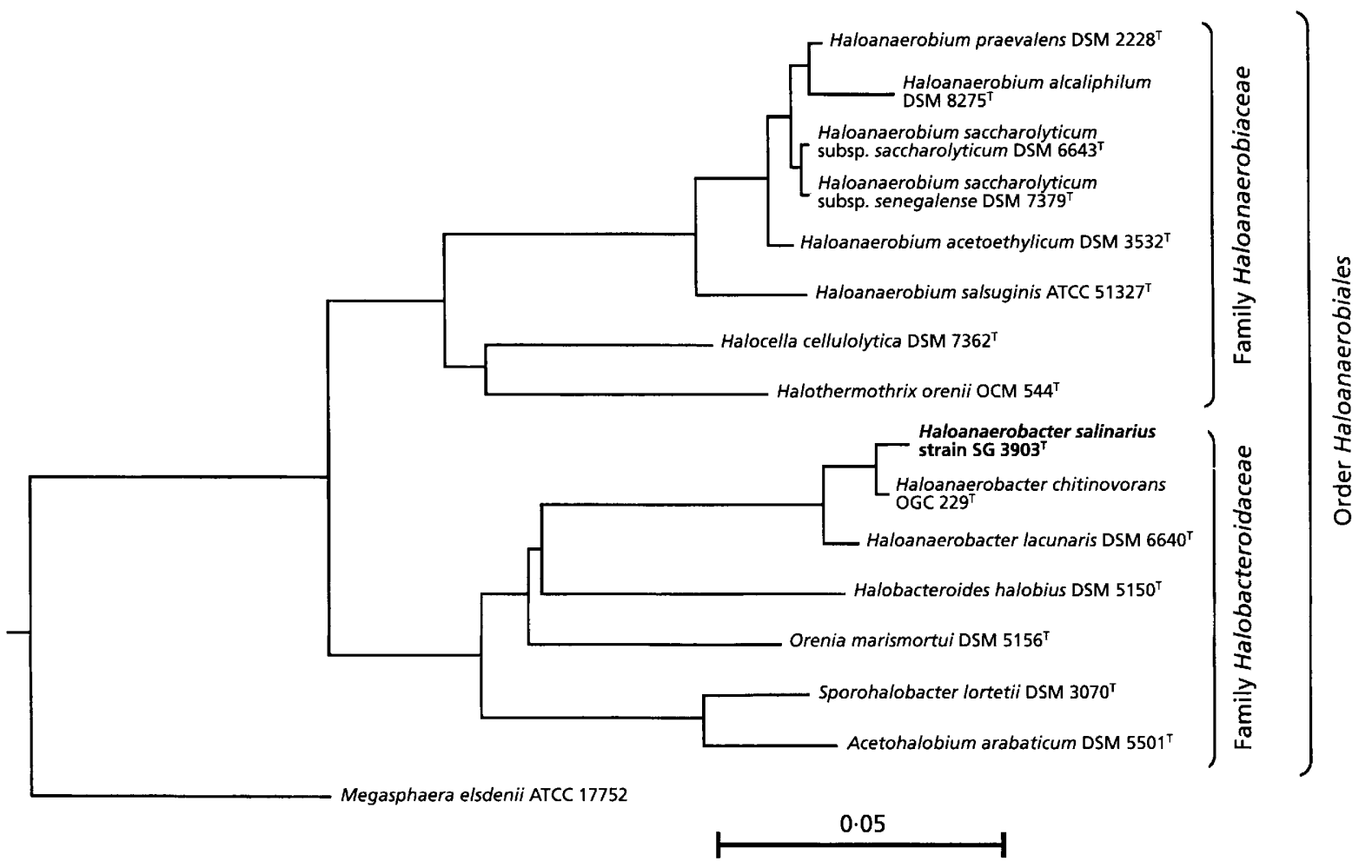

Fig. 5. Dendrogram based on the distance matrix showing genetic relatedness between Haloanaerobacter salinarius strain SG $3903^{\top}$ and related species or genera of the halophilic fermentative bacteria. The 16S rDNA sequence of Megasphaera elsdenii was used as an outgroup to root the tree. Bar, 5 nucleotide substitutions per 100 nucleotides.

Table 3. Comparison of the major properties of Haloanaerobacter species

+ , Positive test result; - , negative test result; $+/-$, some strains with positive test; ND, not determined.

\begin{tabular}{|c|c|c|c|}
\hline Character & $\begin{array}{l}\text { H. salinarius } \\
\text { SG 3903 }\end{array}$ & $\begin{array}{l}\text { H. chitinovorans } \\
\text { OGC } 22^{\mathrm{T}}\end{array}$ & H. lacunaris DSM $6640^{\mathrm{T}}$ \\
\hline Morphology & Long flexible rods & Long flexible rods & Short to long flexible rods \\
\hline Cell size $(\mu \mathrm{m})$ & $0.3-0.4 \times 5-8$ & $0.5 \times 1.4-8$ & $0.7-1 \times 0.5-6$ \\
\hline Motility & + & + & + \\
\hline Flagella & Peritrichous & Peritrichous & Peritrichous \\
\hline $\mathrm{G}+\mathrm{C}$ content $(\mathrm{mol} \%)$ & 31.6 (HPLC) & $34 \cdot 8(\mathrm{Bd})$ & $32 \cdot 4\left(T_{m}\right)$ \\
\hline $\mathrm{NaCl}$ range $(\%)$ & $5-30$ & $3-30$ & $10-30$ \\
\hline Optimum $[\mathrm{NaCl}](\%)$ & $14-15$ & $12-18$ & $15-18$ \\
\hline Temperature range $\left({ }^{\circ} \mathrm{C}\right)$ & $10-50$ & $23-50$ & $5-52$ \\
\hline Temperature optimum $\left({ }^{\circ} \mathrm{C}\right)$ & 45 & $30-45$ & $35-40$ \\
\hline $\mathrm{pH}$ range & $6-8$ & ND & $6-8$ \\
\hline Optimum pH & $7 \cdot 4-7 \cdot 8$ & 7 & $6 \cdot 5-7$ \\
\hline Doubling time (h) & 12 & $2 \cdot 4$ & $2 \cdot 9-4 \cdot 5$ \\
\hline Carbohydrates utilized & + & + & + \\
\hline Chitin degradation & - & $+1-$ & - \\
\hline Amino-acid utilized & - & - & - \\
\hline \multicolumn{4}{|l|}{ Stickland reaction: } \\
\hline Glycine-betaine + serine & + & - & - \\
\hline Glycine-betaine $+\mathrm{H}_{2}$ & + & + & - \\
\hline $\begin{array}{l}\text { End products of glucose } \\
\text { fermentation }\end{array}$ & $\begin{array}{l}\mathrm{H}_{2}, \mathrm{CO}_{2} \text {, acetate, } \\
\text { lactate, propionate, } \\
\text { formate, ethanol }\end{array}$ & $\begin{array}{l}\mathrm{H}_{2}, \mathrm{CO}_{2} \text {, acetate, } \\
\text { isobutyrate }\end{array}$ & $\mathrm{H}_{2}, \mathrm{CO}_{2}$, acetate, ethanol \\
\hline
\end{tabular}


strains are able to use amino acids in Stickland reactions or with hydrogen as electron donor. Type species: Haloanaerobacter chitinovorans.

\section{Description of Haloanaerobacter salinarius sp. nov.}

Haloanaerobacter salinarius (sa.li.na'ri.us. L. adj. salinarius pertaining to salinae salterns, salt-works).

Cells are Gram-negative, colourless, non-sporulating rods, motile by peritrichous flagella; the cells are long, flexible, $0 \cdot 3-0 \cdot 4 \mu \mathrm{m}$ width and 5-8 $\mu \mathrm{m}$ length, in young cultures; short degenerate cells and spheroplasts in old cultures. Surface colonies are circular, translucid, glossy, slightly yellow with entire edges. Colony diameters range from 1 to $2 \mathrm{~mm}$. Agar-embedded colonies are opaque. Obligately halophilic. Growth occurs at $\mathrm{NaCl}$ concentrations of between 5 and $30 \%$; optimal growth at $14-15 \%$. The temperature range for growth is 10 to $50{ }^{\circ} \mathrm{C}$ with an optimal growth at $45^{\circ} \mathrm{C}$. The $\mathrm{pH}$ range is $5.5-8.5$ with the optimum for growth at $\mathrm{pH} 7 \cdot 4-7 \cdot 8$. Cells are susceptible to chloramphenicol and erythromycin, and are resistant to anisomycin, kanamycin, tetracycline and $\mathrm{Na}$-taurocholate. Obligately anaerobic fermentative; catalase- and oxidasenegative. Glucose, fructose, galactose, mannose, trehalose, sucrose, maltose, raffinose, cellobiose, glucosamine, $\mathrm{N}$-acetylglucosamine and mannitol are fermented. The bacteria use glycine-betaine as oxidant in the Stickland reaction which is reductively cleaved into trimethylamine and acetate with hydrogen or serine as electron donors. The major glucose fermentation products are ethanol, propionate, acetate, formate, $\mathrm{CO}_{2}$ and $\mathrm{H}_{2}$. The $\mathrm{G}+\mathrm{C}$ content of the DNA is $31.6 \mathrm{~mol} \%$ (HPLC). Habitat: anoxic organic sediment from solar salterns. Type strain: strain SG $3903^{\mathrm{T}}$, isolated from salt ponds in salterns of Salin-de-Giraud (Camargue, France) and deposited with the DSMZ, number DSM $12146^{\mathrm{T}}$ and the ATCC, number ATCC $700559^{\mathrm{T}}$. 16S rRNA sequence has been deposited in the EMBL Database under the accession number Y14212.

\section{ACKNOWLEDGEMENTS}

This work was partly supported by a grant of the French Ministry of Education and Research (MESR, ACC-SV7). The authors thank the 'Compagnie des Salins-de-Giraud' for its authorization to sample and work in the salterns. $R$. Baulaigue is acknowledged for her technical assistance.

\section{REFERENCES}

Amann, R. I., Ludwig, W. \& Schleifer, K. H. (1995). Phylogenetic identification and in situ detection of individual microbial cells without cultivation. Microbiol Rev 59, 143-169.

Ausubel, F. M., Brent, R., Kingston, R. E., Moore, D. D., Seidman, J. G., Smith, J. A. \& Struhl, K. (1989). Short Protocols in Molecular Biology. New York: Wiley.
Bhupathiraju, V. K., Oren, A., Sharma, P. K., Tanner, R. S., Woese, C. R. \& Mclnerney, M. J. (1994). Haloanaerobium salsugo $\mathrm{sp}$. nov., a moderately halophilic anaerobic bacterium from a subterranean brine. Int $J$ Syst Bacteriol 44, 565-572.

Cashion, P., Hodler-Franklin, M. A., McCully, J. \& Franklin, M. (1977). A rapid method for base ratio determination of bacterial DNA. Anal Biochem 81, 461-466.

Caumette, P. (1993). Ecology and physiology of phototrophic bacteria and sulfate-reducing bacteria in marine salterns. Experientia 49, 473-481.

Caumette, P., Baulaigue, R. \& Matheron, R. (1988). Characterization of Chromatium salexigens sp. nov., a halophilic Chromatiaceae isolated from Mediterranean Salinas. Syst Appl Microbiol 10, 284-292.

Caumette, P., Baulaigue, R. \& Matheron, R. (1991a). Thiocapsa halophila sp. nov., a new halophilic phototrophic purple sulfur bacterium. Arch Microbiol 155, 170-176.

Caumette, P., Cohen, Y. \& Matheron, R. (1991b). Isolation and characterization of Desulfovibrio halophilus sp. nov., a halophilic sulfate-reducing bacterium isolated from Solar Lake (Sinai). Syst Appl Microbiol 14, 33-38.

Caumette, P., Matheron, R., Raymond, N. \& Relexans, J.-C. (1994). Microbial mats in the hypersaline ponds of Mediterranean Salterns (Salin-de-Giraud, France). FEMS Microbiol Ecol 13, 273-286.

Caumette, P., Imhoff, J. F., Süling, J. \& Matheron, R. (1997). Chromatium glycolicum sp. nov., a moderately halophilic purple sulfur bacterium that uses glycolate as substrate. Arch Microbiol 167, 11-18.

Cayol, J.-L., Ollivier, B., Patel, B. K. C., Ageron, E., Grimont, P. A. D., Prensier, G. \& Garcia, J.-L. (1995). Haloanaerobium lacusroseus sp. nov., an extremely halophilic fermentative bacterium from the sediments of a hypersaline lake. Int $J$ Syst Bacteriol 45, 790-797.

De Ley, J., Cattoir, H. \& Reynaerts, A. (1970). The quantitative measurement of DNA hybridization from renaturation rates. Eur $J$ Biochem 12, 133-142.

Escara, J. F. \& Hutton, J. R. (1980). Thermal stability and renaturation of DNA in dimethylsulphoxide solutions: acceleration of renaturation rate. Biopolymers 19, 1315-1327.

Fendrich, C., Hippe, H. \& Gottschalk, G. (1990). Clostridium halophilum $\mathrm{sp}$. nov. and $C$. litorale sp. nov., an obligate halophilic and a marine species degrading betaine in the Stickland reaction. Arch Microbiol 154, 127-132.

Galinski, E. A. \& Trüper, H. G. (1994). Microbial behaviour in salt-stressed ecosystems. FEMS Microbiol Rev 15, 95-108.

Glazer, A. N., Cohen-Bazire, G. \& Stanier, R. Y. (1971). Characterization of phycoerythrin from a Cryptomonas species. Arch Microbiol 80, 1-8.

Heijthuijsen, J. H. F. G. \& Hansen, T. A. (1989). Betaine fermentation and oxidation by marine Desulfuromonas strain. Appl Environ Microbiol 55, 965-969.

Hippe, H., Caspari, D., Fiebig, K. \& Gottschalk, G. (1979). Utilization of trimethylamine and other $N$-methyl compounds for growth and methane formation by Methanosarcina barkeri. Proc Natl Acad Sci USA 75, 494-498.

Huss, V. A. R., Festl, H. \& Schleifer, K. H. (1983). Studies on the spectrometric determination of DNA hybridization from renaturation rates. Syst Appl Microbiol 4, 184-192.

Imhoff, J. F. \& Süling, J. (1996). The phylogenetic relationship among Ectothiorhodospiraceae: a re-evaluation of their tax- 
onomy on the basis of $16 \mathrm{~S}$ rDNA analyses. Arch Microbiol $\mathbf{1 6 5}$, $106-113$

Jahnke, K.-D. (1992). Basic computer program for evaluation of spectroscopic DNA renaturation data from GILFORD Syst 2600 spectrometer on a PC/XT/AT type personal computer. $J$ Microbiol Methods 15, 61-73.

Jukes, T. H. \& Cantor, C. R. (1969). Evolution of protein molecules. In Mammalian Protein Metabolism, vol. 3, pp. 21-132. Edited by H. N. Munro. New York: Academic Press.

Liaw, H. J. \& Mah, R. A. (1992). Isolation and characterization of Haloanaerobacter chitinovorans gen. nov., sp. nov., a halophilic, anaerobic, chitinolytic bacterium from a solar saltern. Appl Environ Microbiol 58, 260-266.

Mesbah, M., Premachandran, U. \& Whitman, W. B. (1989). Precise measurement of the $\mathrm{G}+\mathrm{C}$ content of deoxyribonucleic acid by high-performance liquid chromatography. Int J Syst Bacteriol 39, 159-167.

Möller, B., Oßmer, R., Howard, B. H., Gottschalk, G. \& Hippe, H. (1984). Sporomusa, a new genus of Gram-negative anaerobic bacteria including Sporomusa sphaeroides sp. nov. and Sporomusa ovata sp. nov. Arch Microbiol 139, 388-396.

Möller, B., Hippe, H. \& Gottschalk, G. (1986). Degradation of various amine compounds by mesophilic clostridia. Arch Microbiol 145, 85-90.

Naumann, E., Hippe, H. \& Gottschalk, G. (1983). Betaine: new oxidant in the Stickland reaction and methanogenesis from betaine and L-alanine by Clostridium sporogenesMethanosarcina barkeri coculture. Appl Environ Microbiol 45, $474-483$.

Ollivier, B., Caumette, P., Garcia, J.-L. \& Mah, R. A. (1994). Anaerobic bacteria from hypersaline environments. Microbiol Rev 58, 27-38.

Oren, A. (1990). The use of protein synthesis inhibitors in the estimation of the contribution of halophilic archaebacteria to bacterial activity in hypersaline environments. FEMS Microbiol Ecol 73, 187-192.

Oren, A. (1992). The genera Haloanaerobium, Halobacteroides, and Sporohalobacter. In The Prokaryotes, 2nd edn, vol. 2, pp. 1893-1900. Edited by A. Balows, H. G. Trüper, M. Dworkin, W. Harder \& K. H. Schleifer. New York: Springer.

Overmann, J., Fischer, U. \& Pfennig, N. (1992). A new purple sulfur bacterium from saline littoral sediments, Thiorhodovibrio winogradskyi gen. nov. and sp. nov. Arch Microbiol 157, 329-335.

Patel, B. K. C., Andrews, K. T., Ollivier, B., Mah, R. A. \& Garcia, J.-L. (1995). Re-evaluating the classification of Halobacteroides and Haloanaerobacter species based on sequence comparisons of the 16S ribosomal RNA gene. FEMS Microbiol Lett 134, $115-119$

Pfennig, N. \& Trüper, H. G. (1981). Isolation of members of the families Chromatiaceae and Chlorobiaceae. In The Prokaryotes, vol. 1, pp. 279-289. Edited by M. P. Starr, H. Stolp, H. G. Trüper, A. Balows \& H. G. Schlegel. Berlin \& Heidelberg: Springer.

Pfennig, N. \& Wagener, S. (1986). An improved method of preparing wet mounts for photomicrographs of microorganisms. J Microbiol Methods 4, 303-306.

Pfennig, N., Widdel, F. \& Trüper, H. G. (1981). The dissimilatory sulfate-reducing bacteria. In The Prokaryotes, vol. 1, pp.
926-940. Edited by M. P. Starr, H. Stolp, H. G. Trüper, A. Balows \& H. G. Schlegel. Berlin \& Heidelberg: Springer.

Postgate, J. R. (1984). The Sulphate-reducing Bacteria. Cambridge: Cambridge University Press.

Rainey, F. A., Zhilina, T. N., Bulygina, E. S., Stackebrandt, E., Tourova, T. P. \& Zavarzin, G. A. (1995). The taxonomic status of the fermentative halophilic anaerobic bacteria: description of Haloanaerobiales ord. nov., Halobacteroidaceae fam. nov., Orenia gen. nov. and further taxonomic rearrangements of the genus and species level. Anaerobe 1, 185-199.

Ravot, G., Magot, M., Ollivier, B., Patel, B. K. C., Ageron, E., Grimont, P. A. D., Thomas, P. \& Garcia, J.-L. (1997). Haloanaerobium congolense sp. nov., an anaerobic, moderately halophilic, thiosulfate- and sulfur-reducing bacterium from an African oil field. FEMS Microbiol Lett 147, 81-88.

Sambrook, J., Fritsch, E. F. \& Maniatis, T. (1989). Molecular Cloning: a Laboratory Manual, 2nd edn. Cold Spring Harbor, NY: Cold Spring Harbor Laboratory.

Simankova, M. V., Chernych, N. A., Osipov, G. A. \& Zavarzin, G. A. (1993). Halocella cellulolytica gen. nov., sp. nov., a new obligately anaerobic, halophilic, cellulolytic bacterium. Syst Appl Microbiol 16, 385-389.

Tsai, C.-R., Garcia, J.-L., Patel, B. K. C., Cayol, J.-L., Baresi, L. \& Mah, R. A. (1995). Haloanaerobium alcaliphilum sp. nov., an anaerobic moderate halophile from the sediments of Great Salt Lake, Utah. Int J Syst Bacteriol 45, 301-307.

Vargas, C., Fernandez-Castillo, R., Canovas, D., Ventosa, A. \& Nieto, J. J. (1995). Isolation of cryptic plasmids from moderately halophilic eubacteria of the genus Halomonas. Characterization of a small plasmid from $H$. elongata and its use for shuttle vector construction. Mol Gen Genet 246, 411-418.

Winker, S. \& Woese, C. R. (1991). A definition of the domains Archea, Bacteria and Eucarya in terms of small subunit ribosomal RNA characteristics. Syst Appl Microbiol 13, 161-165.

Yancey, P. H., Clark, M. E., Hand, S. C., Bowlus, R. D. \& Somero, G. N. (1982). Living with water stress: evolution of osmolyte systems. Science 217, 1214-1222.

Zhilina, T. N. \& Zavarzin, G. A. (1990). Extremely halophilic, methylotrophic, anaerobic bacteria. FEMS Microbiol Rev 87, 315-322.

Zhilina, T. N., Kevbrin, V. V., Lysenko, A. M. \& Zavarzin, G. A. (1991a). Isolation of saccharolytic anaerobes from a halophilic cyanobacterial mat. Microbiology (English translation of Mikrobiologiya) 60, 101-107.

Zhilina, T. N., Miroshnikova, L. V., Osipov, G. A. \& Zavarzin, G. A. (1991b). Halobacteroides lacunaris sp. nov., new saccharolytic, anaerobic, extremely halophilic organism from the lagoon-like hypersaline Lake Chokrak. Microbiology (English translation of Mikrobiologiya) 60, 495-503.

Zhilina, T. N., Zavarzin, G. A., Bulygina, E. S., Kevbrin, V. V., Osipov, G. A. \& Chumakov, K. M. (1992). Ecology, physiology and taxonomy studies on a new taxon of Haloanaerobiaceae, Haloincola saccharolytica gen. nov., sp. nov. Syst Appl Microbiol 15, 275-284.

Zhilina, T. N., Zavarzin, G. A., Detkova, E. N. \& Rainey, F. A. (1996). Natroniella acetigena gen. nov. sp. nov., an extremely haloalkaliphilic, homoacetic bacterium: a new member of Haloanaerobiales. Curr Microbiol 32, 320-326. 